\title{
Different prognostic effect of surgery, radiation and chemotherapy in pediatric medulloblastoma less and over three years old: A Surveillance, Epidemiology, and End Results (SEER) analysis
}

\section{Zhong Deng ( $\sim$ dz8981201@126.com )}

First Affiliated Hospital of Sun Yat-sen University https://orcid.org/0000-0002-3510-1376

\section{Yichang Wang}

Xi'an Jiaotong University Medical College First Affiliated Hospital

Xixi Li

Sun Yat-sen University First Affiliated Hospital

Hongxing Tang

Sun Yat-sen University First Affiliated Hospital

Jia Yang

Sun Yat-sen University First Affiliated Hospital

\section{Tuo Wang}

Xi'an Jiaotong University Medical College First Affiliated Hospital

\section{Research Article}

Keywords: Pediatric medulloblastoma, progression, surgery, radiation, chemotherapy

Posted Date: June 16th, 2021

DOl: https://doi.org/10.21203/rs.3.rs-614952/v1

License: (c) (i) This work is licensed under a Creative Commons Attribution 4.0 International License.

Read Full License 


\section{Abstract \\ Introduction}

To clarify the prognostic value of extent of surgical resection, radiation and chemotherapy in pediatric medulloblastoma patients $<3$ years old and $\geq 3$ years old.

\section{Methods}

We used the Surveillance, Epidemiology, and End Results program to identify 1,495 pediatric patients diagnosed between 1973 and 2016 with medulloblastoma. Patients with incomplete or unknown clinical information were excluded. Basic characteristics between patients $<3$ years old and $\geq 3$ years old were compared. Then, we used Cox regression to investigate the impact of extent of surgical resection, radiation and chemotherapy on patient outcome.

\section{Results}

Gross total resection only significantly improved patient outcome in those $\geq 3$ years old, and radiation independently correlated to better OS and PFS in patients $\geq 3$ years old (all $p<0.05$ ). However, chemotherapy only benefited patient outcome in those $<3$ years old (all $p<0.05$ ). Furthermore, in those $\geq$ 3 years old patients underwent surgical procedures, radiation alone confer survival benefit only in those received gross total resection $(p<0.05)$ but not in partial resection or biopsy $(p>0.05)$. Notably, adjuvant radiation plus chemotherapy largely improved patient survival independent of extent of resection $(p<$ 0.05).

\section{Conclusions}

The extent of resection should be differentially considered and applied between pediatric medulloblastoma patients $<3$ years old and $\geq 3$ years old, so are the adjuvant radio- and chemotherapies.

\section{Introduction}

Medulloblastoma is the most common malignant brain tumors in children, comprising for nearly $20 \%$ of pediatric brain tumors and $40 \%$ of all pediatric posterior fossa tumors [1-3]. The main treatments for pediatric medulloblastoma are maximal safe surgical resection, craniospinal radiation (CSI) and systemic chemotherapy $[3,4]$. Due to most common occurrence in brainstem and cerebellum, aggressive surgical resection may be associated with increased postsurgical complications, such as neurologic morbidity and cerebellar mutism. The survival benefit of gross total resection (GTR) is controversial in the literature, which some identify GTR is an independent prognostic factor [5-7], but others do not [8-10]. 
Current clinical risk stratification of medulloblastoma is the main reference for postsurgical therapy, and the stratification separates children into average risk and high-risk strata. High-risk disease is defined by age $<3$ years, subtotal resection (residual tumor $\geq 1.5 \mathrm{~cm}^{2}$ ), or metastasis at diagnosis $[5,7,11-14]$. Maximal safe surgical resection followed by risk adapted CSI and systemic chemotherapy have produced the best survival benefit for pediatric patients aged between 3 and 18 years $[12,13,15,16]$. However, little success is achieved in infant and younger children under 3 years of age. Concerns of neurocognitive impairment limiting the application of CSI in those younger patients may account for the limited benefit. In addition, it is not always available to received risk-adapted and "standard" therapies due to patient adherence and limited resources, especially in low and middle income countries and areas $[3,17]$. Thus, it is important to identify possible prognostic factors in pediatric patients under 3 years of age.

In present study, we used the Surveillance, Epidemiology, and End Results (SEER) database to identify prognostic factors in pediatric medulloblastoma patients. We firstly investigated the frequency of received treatments including surgery, radiation and chemotherapy in medulloblastoma patients with different ages and found that the rate of radiation in patients with age of 0,1 and 2 years is significantly lower than their counterparts with other ages. Then, we classified pediatric medulloblastoma patients into $<3$ years group and $\geq 3$ years group, and compared the difference of basic characteristics and outcomes between these two groups. Lastly, we selected multiple parameters to identify prognostic factors by Cox regression in $<3$ years group and $\geq 3$ years group, respectively.

\section{Methods}

Patient cohort

We used the SEER database to identify 1,495 pediatric patients diagnosed between 2000 and 2016 with medulloblastoma, which were specified by four specific ICD-0-3 codes: 9470/3-medulloblastoma, NOS, 9471/3-desmoplastic nodular medulloblastoma, 9472/3-medullomyoblastoma and 9474/3-large cell medulloblastomas, as previously reported. The age of pediatric patients defined as younger than 18 years old, and patients age of $<1$ year was defined as 0 year old. This study was conducted in accordance with the policies of the Scientific Ethics Committee of SEER program and Sun Yat-sen University.

Study design

As determined by SEER, race was classified as white, African American and others. The extent of surgical resection was defined as: no surgery, biopsy, partial resection (PR) and gross total resection (GTR), which were created to surgical procedure codes as previously described [18]. PR and GTR were defined as surgery performed. Patients received any type of radiation including beam radiation, radioactive implants, raioisotopes, or combinational radiotherapy were classified as radiation used. Patients were excluded if clinical information including race, surgery, tumor resection rate, radiation, histology, chemotherapy and survival months was incomplete or unknown, leaving 939 patients in the final cohort. Overall survival 
(OS) was defined as the time from the diagnosis until death from any cause, and progress free survival (PFS) was defined as the time from diagnosis until death caused by the original brain cancer.

\section{Statistical Analysis}

Baseline patient characteristics were presented as percentages and compared with Chi-Squared test. Multivariable analyses with the Cox proportional-hazards model were used to assess the impact of multiple covariates on patients' OS and PFS. And the selected covariates were age, sex, surgical resection, radiation and chemotherapy. To further clarify the role of radiation and chemotherapy in pediatric medulloblastoma, adjuvant treatment strategy was redefined as none, chemotherapy, radiation, and radiation plus chemotherapy, and then was put into Cox regression analysis. Statistical analysis was carried out using SPSS 22.0 (Chicago, IL, USA). A $p$ value $<0.05$ was considered statistically significant.

\section{Result}

A total of 939 patients were included after exclusion of 556 patients. As shown in Fig. 1, most of the patients aged between 0 to 10 years old. Of these cohort of patients, the number of patients with medulloblastoma, NOS (9470/3), desmoplastic nodular medulloblastoma (9471/3), medullomyoblastoma (9472/3) and large cell medulloblastomas (9474/3) were 784, 101, 3 and 51, respectively (Fig. 1 and Table 1). Due to the concerns of adverse effects, each treatment was differentially applied in every age strata. Only $13.2 \%, 27.8 \%$ and $35.2 \%$ of patients in age of 0,1 and 2 years received radiation, which were significantly lower than that in other age strata, ranging from $74.8-100 \%$ (Fig. 2). However, patients in each age strata received comparable chemotherapy and surgical resection (Fig. 2). 
Table 1

Basic characteristics of medulloblastoma patients with age of $<3$ years and $\geq 3$ years

\begin{tabular}{|c|c|c|c|}
\hline & $<3$ years $(n=196)$ & $\begin{array}{l}\geq 3 \text { years } \\
(n=743)\end{array}$ & $p$ value \\
\hline Sex (Male), n(\%) & $108(55.1)$ & $479(64.5)$ & 0.016 \\
\hline Race, $n(\%)$ & & & 0.397 \\
\hline White & $161(82.1)$ & $629(84.7)$ & \\
\hline Black & $15(7.7)$ & $60(8.1)$ & \\
\hline Others & $20(10.2)$ & $54(7.3)$ & \\
\hline Histology, n(\%) & & & $<0.001$ \\
\hline 9470 & 143(73.0) & $641(86.3)$ & \\
\hline 9471 & $45(23.0)$ & $56(7.5)$ & \\
\hline 9472 & $0(0)$ & $3(0.4)$ & \\
\hline 9474 & $8(4.1)$ & $43(5.8)$ & \\
\hline Surgical resection, $\mathrm{n}(\%)$ & & & 0.088 \\
\hline No surgery & $17(8.7)$ & $44(5.9)$ & \\
\hline Biopsy & $47(24.0)$ & $178(24.0)$ & \\
\hline Partial resection & $41(20.9)$ & $115(15.5)$ & \\
\hline Gross total resection & $91(46.4)$ & $406(54.6)$ & \\
\hline Radiation, n(\%) & $53(27.0)$ & $631(84.9)$ & $<0.001$ \\
\hline Chemotherapy, n(\%) & $165(84.2)$ & $641(86.3)$ & 0.456 \\
\hline 6-month survival, n(\%) & 157(80.5) & $700(94.7)$ & $<0.001$ \\
\hline 1-year survival, n(\%) & 135(69.2) & $656(88.8)$ & $<0.001$ \\
\hline 3-year survival, n(\%) & 113(57.9) & $553(74.8)$ & $<0.001$ \\
\hline 5-year survival, n(\%) & $103(52.8)$ & $502(67.9)$ & $<0.001$ \\
\hline 10-year survival, n(\%) & $56(28.7)$ & $255(34.5)$ & 0.127 \\
\hline \multicolumn{4}{|c|}{$\begin{array}{l}9470 / 3 \text {, medulloblastoma, NOS; } 9471 / 3 \text {, desmoplastic nodular medulloblastoma; } 9472 / 3 \text {, } \\
\text { medullomyoblastoma; } 9474 / 3 \text {, large cell medulloblastomas; PR, partial resection; GTR, gross total } \\
\text { resection. The same for the following tables. }\end{array}$} \\
\hline
\end{tabular}

Hence, we classified the cohort of patients into $<3$ years group and $\geq 3$ years group and compared the difference of basic characteristics. Consistent to the previous report that the incidence of 
medulloblastoma is higher in male, and even higher in $\geq 3$ years group ( $55.1 \%$ vs $64.5 \%, p=0.016)$ (Table 1). There are more desmoplastic nodular medulloblastoma cases ( $23.0 \%$ vs $7.5 \%)$, lower rate of GTR $(46.4 \%$ vs $54.6 \%)$ and less radiation $(27.0 \%$ vs $84.9 \%, p<0.001)$ in $<3$ years group. However, patients in both groups received comparable chemotherapy $(84.2 \%$ vs $86.3 \%, p=0.456)$. As expected, the outcome of patients younger than 3 years old was much worse compared to their counterparts, and the rate of 6month survival, 1-year survival, 3-year survival, 5-year survival and 10-year survival was $80.5 \%$ vs $94.7 \%$ $(p<0.001), 69.2$ vs $88.8 \%(p<0.001), 57.9 \%$ vs $74.8 \%(p<0.001), 52.8 \%$ vs $67.9 \%(p<0.001)$ and $28.7 \%$ vs $34.5 \%(p=0.127)$ between those two groups, respectively (Table 1$)$.

To identify prognostic risk factors, parameters including age, sex, histology, surgical resection, radiation and chemotherapy were selected for Cox regression analysis for both groups. We found that patients age, chemotherapy independently benefit patient OS $(p<0.001)$ and PFS $(p=0.008)$, however, radiation and extent of resection did not in $<3$ years group (Table 2). For those patients $\geq 3$ years patients, the more frequently applied radiation significantly prolonged patient OS and PFS (all $p<0.001$ ) (Table 3 ). Unlike $<3$ years group, surgery performed could significantly prolong patient OS $(p<0.05)$ (Table 3$)$. However, chemotherapy did not benefit patient outcome $(p>0.05)$ (Table 3$)$. In both groups, desmoplastic nodular medulloblastoma negatively correlated to patient outcome compared to medulloblastoma, NOS $(p<0.05)$ (Tables 2 and 3).

Table 2

Hazard Ratios for overall survival and progress free survival in medulloblastoma patients aged $<3$ years old

\begin{tabular}{|lllll|}
\hline & OS & & \multicolumn{2}{l|}{ PFS } \\
\hline & p value & $95 \% \mathrm{Cl}$ & $\mathrm{p}$ value & $95 \% \mathrm{Cl}$ \\
\hline Age & 0.152 & $0.808(0.604-1.081)$ & 0.868 & $1.030(0.731-1.450)$ \\
\hline Sex & 0.629 & $1.117(0.712-1.753)$ & 0.534 & $1.180(0.700-1.989)$ \\
\hline Resection & & & & \\
(No surgery) & & & & \\
\hline Biopsy & 0.375 & $0.683(0.294-1.587)$ & 0.734 & $0.826(0.273-2.496)$ \\
\hline PR & 0.494 & $0.750(0.329-1.711)$ & 0.789 & $1.154(0.404-3.297)$ \\
\hline GTR & 0.664 & $0.841(0.385-1.838)$ & 0.843 & $1.109(0.399-3.082)$ \\
\hline Radiation & 0.172 & $0.667(0.373-1.192)$ & 0.167 & $0.634(0.332-1.210)$ \\
\hline Chemotherapy & $<0.001$ & $0.330(0.179-0.609)$ & 0.008 & $0.362(0.171-0.767)$ \\
\hline Histology (9470) & & & & \\
\hline 9471 & 0.023 & $0.456(0.232-0.897)$ & 0.028 & $0.406(0.182-0.906)$ \\
\hline 9474 & 0.006 & $2.938(1.367-6.311)$ & 0.008 & $3.335(1.362-8.168)$ \\
\hline
\end{tabular}


Table 3

Hazard Ratios for overall survival and progress free survival in medulloblastoma patients aged $\geq 3$ years old

\begin{tabular}{|c|c|c|c|c|}
\hline & OS & & PFS & \\
\hline & $p$ value & $95 \% \mathrm{Cl}$ & $p$ value & $95 \% \mathrm{Cl}$ \\
\hline Age & 0.210 & $0.979(0.947-1.012)$ & 0.199 & $0.976(0.940-1.013)$ \\
\hline Sex & 0.919 & $1.014(0.780-1.317)$ & 0.224 & $0.829(0.613-1.122)$ \\
\hline \multicolumn{5}{|l|}{$\begin{array}{l}\text { Resection } \\
\text { (No surgery) }\end{array}$} \\
\hline Biopsy & 0.005 & $0.480(0.287-0.803)$ & 0.66 & $0.854(0.422-1.727)$ \\
\hline PR & 0.049 & $0.587(0.344-0.999)$ & 0.868 & $1.063(0.518-2.182)$ \\
\hline GTR & 0.001 & $0.449(0.277-0.729)$ & 0.463 & $0.776(0.292-1.520)$ \\
\hline Radiation & $<0.001$ & $0.394(0.269-0.578)$ & $<0.001$ & $0.405(0.264-0.621)$ \\
\hline Chemotherapy & 0.722 & $0.927(0.611-1.407)$ & 0.923 & $1.024(0.631-1.662)$ \\
\hline \multicolumn{5}{|c|}{ Histology (9470) } \\
\hline 9471 & 0.082 & $0.568(0.301-1.074)$ & 0.146 & $0.607(0.310-1.189)$ \\
\hline 9472 & 0.162 & $2.731(0.669-11.150)$ & 0.070 & $3.701(0.900-15.215)$ \\
\hline 9474 & 0.008 & $1.878(1.180-2.988)$ & 0.003 & $2.092(1.280-3.420)$ \\
\hline
\end{tabular}

Since less concerns of adverse effect of adjuvant radiation and chemotherapy in patients over 3 years old, we further clarified the survival benefit of radiation and chemotherapy in those patients who underwent biopsy, PR or GTR. Parameters including age, sex, histology and adjuvant therapy were selected for Cox regression. Radiation alone did improve patient outcome in those received PR or GTR, but not in those received biopsy (Tables 4 and 5). Surprisingly, chemotherapy alone could not benefit patient OS $(p>0.05)$ and PFS $(p>0.05)$ neither in those underwent biopsy, PR or GTR (Tables 4 and 5$)$. And radiation could only significantly prolong patient OS ( $p=0.011 ; \mathrm{OR} 0.230 ; 95 \% \mathrm{Cl}, 0.074$ to 0.716 ) and PFS ( $p=0.017$; OR $0.206,95 \% \mathrm{Cl}, 0.056$ to 0.754$)$ in those received GTR. Noteworthy, radiation plus chemotherapy significantly improved patient outcome even more (Tables 4 and 5). 
Table 4

Hazard Ratios of adjuvant therapy for overall survival in medulloblastoma patients $\geq 3$ years old underwent surgery

\begin{tabular}{|c|c|c|c|c|c|c|}
\hline \multirow[t]{2}{*}{ Adjuvant therapy } & \multicolumn{2}{|c|}{ Biopsy } & \multicolumn{2}{|l|}{ PR } & \multicolumn{2}{|l|}{ GTR } \\
\hline & $\begin{array}{l}\mathrm{p} \\
\text { value }\end{array}$ & $95 \% \mathrm{Cl}$ & $\begin{array}{l}\mathrm{p} \\
\text { value }\end{array}$ & $95 \% \mathrm{Cl}$ & $\begin{array}{l}\mathrm{p} \\
\text { value }\end{array}$ & $95 \% \mathrm{Cl}$ \\
\hline \multirow[t]{2}{*}{ Chemotherapy } & 0.921 & 1.060 & 0.803 & 0.799 & 0.334 & 0.673 \\
\hline & & $\begin{array}{l}(0.332- \\
3.386)\end{array}$ & & $\begin{array}{l}(0.137- \\
4.663)\end{array}$ & & $\begin{array}{l}(0.301- \\
1.504)\end{array}$ \\
\hline \multirow[t]{2}{*}{ Radiation } & 0.654 & 0.738 & 0.975 & & 0.011 & 0.230 \\
\hline & & $\begin{array}{l}(0.196- \\
2.785)\end{array}$ & & & & $\begin{array}{l}(0.074- \\
0.716)\end{array}$ \\
\hline \multirow{2}{*}{$\begin{array}{l}\text { Radio- and Chemo- } \\
\text { therapy }\end{array}$} & 0.078 & 0.430 & 0.039 & 0.381 & $<$ & 0.271 \\
\hline & & $\begin{array}{l}(0.168- \\
1.099)\end{array}$ & & $\begin{array}{l}(0.153- \\
0.952)\end{array}$ & & $\begin{array}{l}(0.148- \\
0.496)\end{array}$ \\
\hline
\end{tabular}

Table 5

Hazard Ratios of adjuvant therapy for progress free survival in medulloblastoma patients $\geq 3$ years old underwent surgery

\begin{tabular}{|c|c|c|c|c|c|c|}
\hline \multirow[t]{2}{*}{ Adjuvant therapy } & \multicolumn{2}{|c|}{ Biopsy } & \multicolumn{2}{|l|}{ PR } & \multicolumn{2}{|l|}{ GTR } \\
\hline & $\begin{array}{l}p \\
\text { value }\end{array}$ & $95 \% \mathrm{Cl}$ & $\begin{array}{l}\mathrm{p} \\
\text { value }\end{array}$ & $95 \% \mathrm{Cl}$ & $\begin{array}{l}\mathrm{p} \\
\text { value }\end{array}$ & $95 \% \mathrm{Cl}$ \\
\hline \multirow[t]{2}{*}{ Chemotherapy } & 0.624 & 1.364 & 0.965 & 0.962 & 0.263 & 0.596 \\
\hline & & $\begin{array}{l}(0.394- \\
4.726)\end{array}$ & & $\begin{array}{l}(0.164- \\
5.641)\end{array}$ & & $\begin{array}{l}(0.241- \\
1.474)\end{array}$ \\
\hline \multirow[t]{2}{*}{ Radiation } & 0.882 & 0.899 & 0.977 & & 0.017 & 0.206 \\
\hline & & $\begin{array}{l}(0.221- \\
3.662)\end{array}$ & & & & $\begin{array}{l}(0.056- \\
0.754)\end{array}$ \\
\hline \multirow{2}{*}{$\begin{array}{l}\text { Radio- and Chemo- } \\
\text { therapy }\end{array}$} & \multirow[t]{2}{*}{0.118} & 0.433 & 0.045 & 0.369 & \multirow{2}{*}{$<.001$} & 0.273 \\
\hline & & $\begin{array}{l}(0.151- \\
1.238)\end{array}$ & & $\begin{array}{l}(0.140- \\
0.977)\end{array}$ & & $\begin{array}{l}(0.140- \\
0.529)\end{array}$ \\
\hline
\end{tabular}

\section{Discussion}

In present study, we firstly found that there was more desmoplastic nodular medulloblastoma cases $(20.9 \%$ ) in patients $<3$ years (Fig. 1 and Table 1), however, which is lower than $44 \%$ in the previous reports [14]. Secondly, radiation was less frequently applied in patients $<3$ years, which is consistent to the clinical practice of reduced or delayed application of radiation in those patients due to concerns of 
neurocognitive impairment $[19,20]$. Thirdly, we identified that patients $<3$ years was really in high risk compared to patients $\geq 3$ years with lower 6-month, 1-year, 3-year and 5-year survival rate. Differential epidemiological characteristics, such as age and histology, and application of radiation as shown in Table 1 might account for survival difference between patients $<3$ years old and $\geq 3$ years old. Indeed, before use of CSI, medulloblastoma remains incurable in older children even with GTR $[4,21]$.

In the literature, the benefit of GTR remains controversial. Albright et al [6] and Zeltzer et al [7] reported survival benefit of GTR over PR or biopsy in patients $>3$ years old, however, no significance was found in Akyuz's study with patients age of 0 to 18 years old [9] and in Evans's study with patients age of 2 to 16 years old [10]. The above studies implied that age might affect significance of GTR in survival. In a large retrospective study, Thompson et al found significant interaction between age and extent of resection, however, they did report overall and progress-free survival benefit of GTR compared to near total resection and subtotal resection in patients $<3$ years old [5]. Notably, the prognostic benefit of increased extent of resection was attenuated when molecular subgroup affiliation is taken into account [5]. Similarly, the present study demonstrated that GTR did not confer OS and PFS benefit in patients $<3$ years old (Table 2). However, GTR showed OS benefit but no PFS benefit in $\geq 3$ years old group (Table 3 ).

It is well established that radiation alone could largely improve patient perspective and cure the disease $[4,21]$. Early studies elicited that chemotherapy alone could prolong tumor free survival in younger children less than 18 months of age [22]. For those patients aged $<5$ years old, Grill et al proved that conventional chemotherapy alone was sufficient to cure patients who had GTR, but not those with incompletely resection or metastatic medulloblastoma [20]. The present study identified that chemotherapy but not radiation significantly improved OS and PFS in younger patients $<3$ years old (Table 2), however, the OS and PFS benefit of chemotherapy and radiation was inverted in those patients $\geq 3$ years old (Table 3). Different sensitivity of histological subtypes to chemotherapy might account for the difference between patients $<3$ years old and $\geq 3$ years old $[23,24]$, since there are more desmoplastic nodular medulloblastoma cases in $<3$ years old patients. Furthermore, in those patients $\geq 3$ years old and underwent surgical procedures, the benefit of radiation alone largely depends on the extent of resection (Tables 4 and 5). It is worth noting that adjuvant radiation together with chemotherapy largely improves patient outcome even in those underwent partial resection (Tables 4 and 5).

With the introduction of molecular diagnosis by the 2016 WHO classification of central nervous system tumor [25], different molecular subtype and origin of medulloblastoma determine the sensitivity to chemo-, radio- or targeting therapy $[4,5,26,27]$. Hence, pathological diagnosis from surgical procedures is highly recommended in the treatment of pediatric medulloblastoma. Due to apparent reasons, the epidemiology of molecular subtype and its impact on the outcome of pediatric medulloblastoma is out of the scope of the study.

Due to limited cases, we were unable to further investigate the survival benefit of radiation and chemotherapy in medulloblastoma patients less than 3 years old who received biopsy, PR or GTR. Also, the study is subject to inherent limitations of retrospective study. The treatment patterns might vary from 
each patient and doctor, and the "standard" treatments including radio- and chemo- therapy differ from each year or each version of guideline. Moreover, the further details of radiation or chemotherapy are largely unknown and might impact the results of present studies and cause bias.

Notwithstanding these limitations, data from present study demonstrates that the extent of surgical resection confer overall survival benefit in those $\geq 3$ years old patients but not in those $<3$ years old. Chemotherapy shows OS and PFS benefit in those $\geq 3$ years old patients but not in those $<3$ years old, however, radiation shows inverted effect between those two populations. Moreover, adjuvant radiation plus chemotherapy largely is the most effective adjuvant treatment for those underwent tumor resection. In conclusion, the extent of resection should be differentially considered and applied between pediatric medulloblastoma patients $<3$ years old and $\geq 3$ years old, so are the adjuvant treatments.

\section{Declarations}

The authors declare that the work described is original work and is not under review by any other journal. The data access is approved by the SEER program and the usage is in accordance to the policies of SEER program.

\section{Funding}

Not applicable.

\section{Conflicts of interest}

There is no conflict of interest exits in the submission of this manuscript.

\section{Availability of data and material}

In the present study, all data were selected from the Surveillance, Epidemiology, and End Results (SEER) database. Researchers can request and get access to the data at https://seer.cancer.gov.

\section{Authors' contributions}

Zhong Deng and Tuo Wang designed and conducted this research. Yichang Wang and Xixi Li contribute equally to the present work. Yichang Wang and Xixi Li collected and analyzed all data. Hongxi Tang and Jia Yang contributed the Tables and Figures composition. Zhong Deng and Tuo wang wrote and revised the manuscript together.

\section{Ethics approval}

The study is conducted in accordance with the policies of the Scientific Ethics Committee of Sun Yat-sen University.

\section{Consent to participate}


Not applicable.

\section{Consent for publication}

All the authors have read the final version of this manuscript and approved for publication.

\section{References}

1. Ostrom QT, de Blank PM, Kruchko C, Petersen CM, Liao P, Finlay JL, Stearns DS, Wolff JE, Wolinsky Y, Letterio JJ, Barnholtz-Sloan JS (2015) Alex's Lemonade Stand Foundation Infant and Childhood Primary Brain and Central Nervous System Tumors Diagnosed in the United States in 2007-2011. Neuro-oncology 16 Suppl 10: x1-x36 doi:10.1093/neuonc/nou327

2. Khanna V, Achey RL, Ostrom QT, Block-Beach H, Kruchko C, Barnholtz-Sloan JS, de Blank PM (2017) Incidence and survival trends for medulloblastomas in the United States from 2001 to 2013. Journal of neuro-oncology 135:433-441. doi:10.1007/s11060-017-2594-6

3. Parkes J, Hendricks M, Ssenyonga P, Mugamba J, Molyneux E, Schouten-van Meeteren A, Qaddoumi I, Fieggen G, Luna-Fineman S, Howard S, Mitra D, Bouffet E, Davidson A, Bailey S (2015) SIOP PODC adapted treatment recommendations for standard-risk medulloblastoma in low and middle income settings. Pediatr Blood Cancer 62:553-564. doi:10.1002/pbc.25313

4. Northcott PA, Robinson GW, Kratz CP, Mabbott DJ, Pomeroy SL, Clifford SC, Rutkowski S, Ellison DW, Malkin D, Taylor MD, Gajjar A, Pfister SM (2019) Medulloblastoma. Nat Rev Dis Primers 5:11. doi:10.1038/s41572-019-0063-6

5. Thompson EM, Hielscher T, Bouffet E, Remke M, Luu B, Gururangan S, McLendon RE, Bigner DD, Lipp ES, Perreault S, Cho YJ, Grant G, Kim SK, Lee JY, Rao AAN, Giannini C, Li KKW, Ng HK, Yao Y, Kumabe T, Tominaga T, Grajkowska WA, Perek-Polnik M, Low DCY, Seow WT, Chang KTE, Mora J, Pollack IF, Hamilton RL, Leary S, Moore AS, Ingram WJ, Hallahan AR, Jouvet A, Fèvre-Montange M, Vasiljevic A, Faure-Conter C, Shofuda T, Kagawa N, Hashimoto N, Jabado N, Weil AG, Gayden T, Wataya T, Shalaby T, Grotzer M, Zitterbart K, Sterba J, Kren L, Hortobágyi T, Klekner A, László B, Pócza T, Hauser P, Schüller U, Jung S, Jang WY, French PJ, Kros JM, van Veelen MC, Massimi L, Leonard JR, Rubin JB, Vibhakar R, Chambless LB, Cooper MK, Thompson RC, Faria CC, Carvalho A, Nunes S, Pimentel J, Fan X, Muraszko KM, López-Aguilar E, Lyden D, Garzia L, Shih DJH, Kijima N, Schneider C, Adamski J, Northcott PA, Kool M, Jones DTW, Chan JA, Nikolic A, Garre ML, Van Meir EG, Osuka S, Olson JJ, Jahangiri A, Castro BA, Gupta N, Weiss WA, Moxon-Emre I, Mabbott DJ, Lassaletta A, Hawkins CE, Tabori U, Drake J, Kulkarni A, Dirks P, Rutka JT, Korshunov A, Pfister SM, Packer RJ, Ramaswamy V, Taylor MD (2016) Prognostic value of medulloblastoma extent of resection after accounting for molecular subgroup: a retrospective integrated clinical and molecular analysis. The Lancet Oncology 17:484-495. doi:10.1016/s1470-2045(15)00581-1

6. Albright AL, Wisoff JH, Zeltzer PM, Boyett JM, Rorke LB, Stanley P (1996) Effects of medulloblastoma resections on outcome in children: a report from the Children's Cancer Group. Neurosurgery 38:265-271. doi:10.1097/00006123-199602000-00007 
7. Zeltzer PM, Boyett JM, Finlay JL, Albright AL, Rorke LB, Milstein JM, Allen JC, Stevens KR, Stanley P, Li H, Wisoff JH, Geyer JR, McGuire-Cullen P, Stehbens JA, Shurin SB, Packer RJ (1999) Metastasis stage, adjuvant treatment, and residual tumor are prognostic factors for medulloblastoma in children: conclusions from the Children's Cancer Group 921 randomized phase III study. Journal of clinical oncology: official journal of the American Society of Clinical Oncology 17:832-845. doi:10.1200/jco.1999.17.3.832

8. Johnston DL, Keene D, Bartels U, Carret AS, Crooks B, Eisenstat DD, Fryer C, Lafay-Cousin L, Larouche V, Moghrabi A, Wilson B, Zelcer S, Silva M, Brossard J, Bouffet E (2009) Medulloblastoma in children under the age of three years: a retrospective Canadian review. Journal of neuro-oncology 94:51-56. doi:10.1007/s11060-009-9799-2

9. Akyüz C, Varan A, Küpeli S, Akalan N, Söylemezoglu F, Zorlu F, Kutluk T, Büyükpamukçu M (2008) Medulloblastoma in children: a 32-year experience from a single institution. Journal of neurooncology 90:99-103. doi:10.1007/s11060-008-9638-x

10. Evans AE, Jenkin RD, Sposto R, Ortega JA, Wilson CB, Wara W, Ertel IJ, Kramer S, Chang CH, Leikin SL et al (1990) The treatment of medulloblastoma. Results of a prospective randomized trial of radiation therapy with and without $\mathrm{CCNU}$, vincristine, and prednisone. Journal of neurosurgery 72:572-582. doi:10.3171/jns.1990.72.4.0572

11. Harisiadis L, Chang $\mathrm{CH}$ (1977) Medulloblastoma in children: a correlation between staging and results of treatment. Int J Radiat Oncol Biol Phys 2:833-841. doi:10.1016/0360-3016(77)90181-x

12. Gajjar A, Chintagumpala M, Ashley D, Kellie S, Kun LE, Merchant TE, Woo S, Wheeler G, Ahern V, Krasin MJ, Fouladi M, Broniscer A, Krance R, Hale GA, Stewart CF, Dauser R, Sanford RA, Fuller C, Lau C, Boyett JM, Wallace D, Gilbertson RJ (2006) Risk-adapted craniospinal radiotherapy followed by high-dose chemotherapy and stem-cell rescue in children with newly diagnosed medulloblastoma (St Jude Medulloblastoma-96): long-term results from a prospective, multicentre trial. The Lancet Oncology 7:813-820. doi:10.1016/s1470-2045(06)70867-1

13. Packer RJ, Gajjar A, Vezina G, Rorke-Adams L, Burger PC, Robertson PL, Bayer L, LaFond D, Donahue BR, Marymont MH, Muraszko K, Langston J, Sposto R (2006) Phase III study of craniospinal radiation therapy followed by adjuvant chemotherapy for newly diagnosed average-risk medulloblastoma. Journal of clinical oncology: official journal of the American Society of Clinical Oncology 24:4202-4208. doi:10.1200/jco.2006.06.4980

14. Rutkowski S, von Hoff K, Emser A, Zwiener I, Pietsch T, Figarella-Branger D, Giangaspero F, Ellison DW, Garre ML, Biassoni V, Grundy RG, Finlay JL, Dhall G, Raquin MA, Grill J (2010) Survival and prognostic factors of early childhood medulloblastoma: an international meta-analysis. Journal of clinical oncology: official journal of the American Society of Clinical Oncology 28:4961-4968. doi:10.1200/jco.2010.30.2299

15. von Bueren AO, Kortmann RD, von Hoff K, Friedrich C, Mynarek M, Müller K, Goschzik T, Zur Mühlen A, Gerber N, Warmuth-Metz M, Soerensen N, Deinlein F, Benesch M, Zwiener I, Kwiecien R, Faldum A, Bode U, Fleischhack G, Hovestadt V, Kool M, Jones D, Northcott P, Kuehl J, Pfister S, Pietsch T, Rutkowski S (2016) Treatment of Children and Adolescents With Metastatic Medulloblastoma and 
Prognostic Relevance of Clinical and Biologic Parameters. Journal of clinical oncology: official journal of the American Society of Clinical Oncology 34:4151-4160. doi:10.1200/jco.2016.67.2428

16. Lannering B, Rutkowski S, Doz F, Pizer B, Gustafsson G, Navajas A, Massimino M, Reddingius R, Benesch M, Carrie C, Taylor R, Gandola L, Björk-Eriksson T, Giralt J, Oldenburger F, Pietsch T, FigarellaBranger D, Robson K, Forni M, Clifford SC, Warmuth-Metz M, von Hoff K, Faldum A, Mosseri V, Kortmann R (2012) Hyperfractionated versus conventional radiotherapy followed by chemotherapy in standard-risk medulloblastoma: results from the randomized multicenter HIT-SIOP PNET 4 trial. Journal of clinical oncology: official journal of the American Society of Clinical Oncology 30:31873193. doi:10.1200/jco.2011.39.8719

17. Kruger M, Hendricks M, Davidson A, Stefan CD, van Eyssen AL, Uys R, van Zyl A, Hesseling P (2014) Childhood cancer in Africa. Pediatr Blood Cancer 61:587-592. doi:10.1002/pbc.24845

18. Dey M, Lin Y, Melkonian S, Lam S (2014) Prognostic factors and survival in primary adult high grade brainstem astrocytoma: a population based study from 1973-2008. J Clin Neurosci 21:1298-1303. doi:10.1016/j.jocn.2013.12.011

19. Sirachainan N, Nuchprayoon I, Thanarattanakorn P, Pakakasama S, Lusawat A, Visudibhan A, Dhanachai M, Larbcharoensub N, Amornfa J, Shotelersuk K, Katanyuwong K, Tangkaratt S, Hongeng $S$ (2011) Outcome of medulloblastoma in children treated with reduced-dose radiation therapy plus adjuvant chemotherapy. J Clin Neurosci 18:515-519. doi:10.1016/j.jocn.2010.08.012

20. Grill J, Sainte-Rose C, Jouvet A, Gentet JC, Lejars O, Frappaz D, Doz F, Rialland X, Pichon F, Bertozzi Al, Chastagner P, Couanet D, Habrand JL, Raquin MA, Le Deley MC, Kalifa C (2005) Treatment of medulloblastoma with postoperative chemotherapy alone: an SFOP prospective trial in young children. The Lancet Oncology 6:573-580. doi:10.1016/s1470-2045(05)70252-7

21. Bloom HJ (1982) Medulloblastoma in children: increasing survival rates and further prospects. Int $J$ Radiat Oncol Biol Phys 8:2023-2027. doi:10.1016/0360-3016(82)90466-7

22. Geyer JR, Zeltzer PM, Boyett JM, Rorke LB, Stanley P, Albright AL, Wisoff JH, Milstein JM, Allen JC, Finlay JL et al (1994) Survival of infants with primitive neuroectodermal tumors or malignant ependymomas of the CNS treated with eight drugs in 1 day: a report from the Childrens Cancer Group. Journal of clinical oncology: official journal of the American Society of Clinical Oncology 12:1607-1615. doi:10.1200/jco.1994.12.8.1607

23. Dhall G, O'Neil SH, Ji L, Haley K, Whitaker AM, Nelson MD, Gilles F, Gardner SL, Allen JC, Cornelius AS, Pradhan K, Garvin JH, Olshefski RS, Hukin J, Comito M, Goldman S, Atlas MP, Walter AW, Sands S, Sposto R, Finlay JL (2020) Excellent outcome of young children with nodular desmoplastic medulloblastoma treated on "Head Start" III: a multi-institutional, prospective clinical trial. Neurooncology 22:1862-1872. doi:10.1093/neuonc/noaa102

24. AbdelBaki MS, Boué DR, Finlay JL, Kieran MW (2018) Desmoplastic nodular medulloblastoma in young children: a management dilemma. Neurooncology 20:1026-1033.

doi:10.1093/neuonc/nox222 
25. Louis DN, Perry A, Reifenberger G, von Deimling A, Figarella-Branger D, Cavenee WK, Ohgaki H, Wiestler OD, Kleihues P, Ellison DW (2016) The 2016 World Health Organization Classification of Tumors of the Central Nervous System: a summary. Acta Neuropathol 131:803-820. doi:10.1007/s00401-016-1545-1

26. Robinson GW, Rudneva VA, Buchhalter I, Billups CA, Waszak SM, Smith KS, Bowers DC, Bendel A, Fisher PG, Partap S, Crawford JR, Hassall T, Indelicato DJ, Boop F, Klimo P, Sabin ND, Patay Z, Merchant TE, Stewart CF, Orr BA, Korbel JO, Jones DTW, Sharma T, Lichter P, Kool M, Korshunov A, Pfister SM, Gilbertson RJ, Sanders RP, Onar-Thomas A, Ellison DW, Gajjar A, Northcott PA (2018) Riskadapted therapy for young children with medulloblastoma (SJYC07): therapeutic and molecular outcomes from a multicentre, phase 2 trial. The Lancet Oncology 19:768-784. doi:10.1016/s14702045(18)30204-3

27. Ramaswamy V, Remke M, Bouffet E, Faria CC, Perreault S, Cho YJ, Shih DJ, Luu B, Dubuc AM, Northcott PA, Schüller U, Gururangan S, McLendon R, Bigner D, Fouladi M, Ligon KL, Pomeroy SL, Dunn S, Triscott J, Jabado N, Fontebasso A, Jones DT, Kool M, Karajannis MA, Gardner SL, Zagzag D, Nunes S, Pimentel J, Mora J, Lipp E, Walter AW, Ryzhova M, Zheludkova O, Kumirova E, Alshami J, Croul SE, Rutka JT, Hawkins C, Tabori U, Codispoti KE, Packer RJ, Pfister SM, Korshunov A, Taylor MD (2013) Recurrence patterns across medulloblastoma subgroups: an integrated clinical and molecular analysis. The Lancet Oncology 14:1200-1207. doi:10.1016/s1470-2045(13)70449-2

\section{Figures}




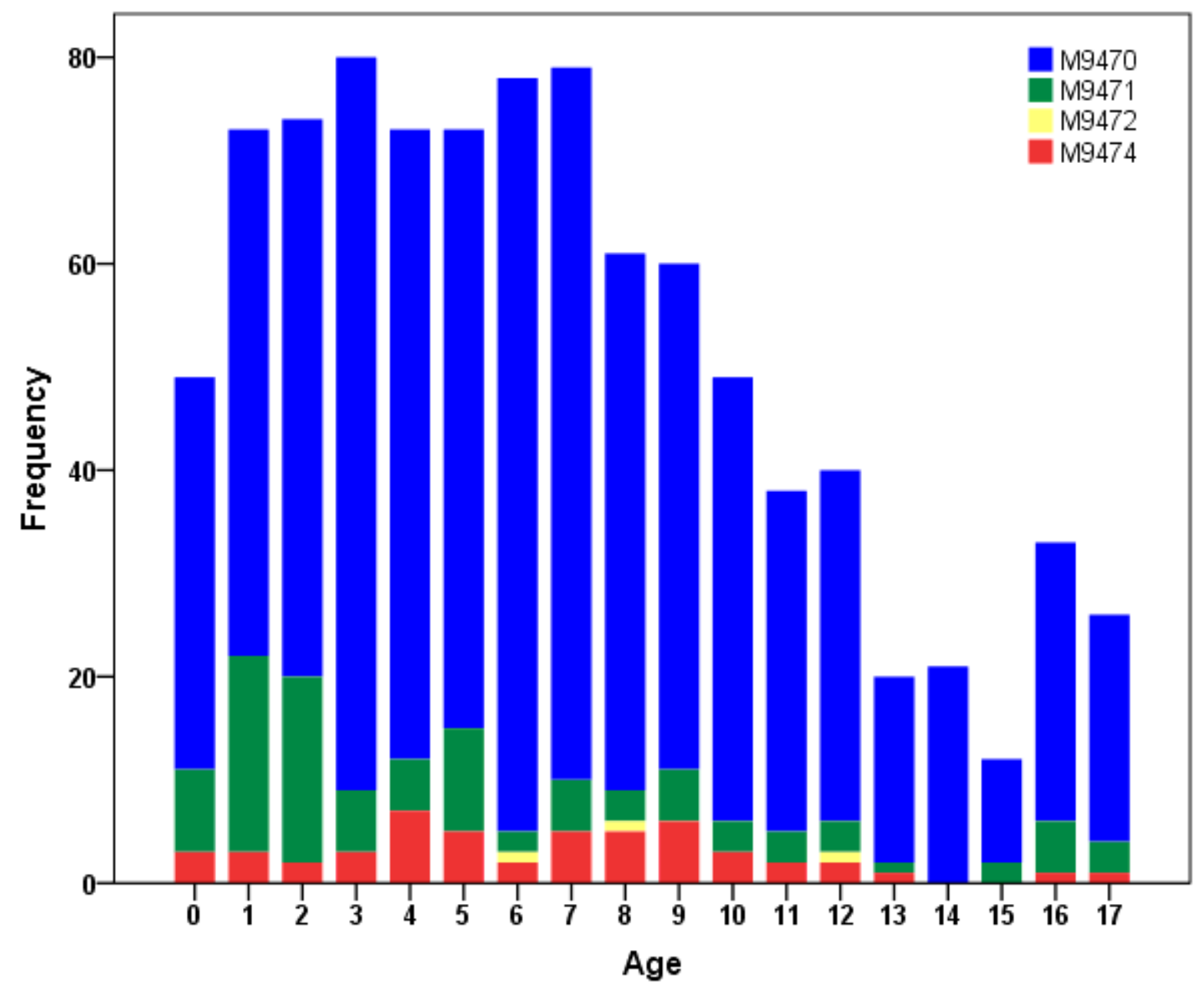

Figure 1

Histogram represents the frequency of each subtype of medulloblastoma in every age strata. Medulloblastoma ICD-0-3 codes: 9470, medulloblastoma, NOS; 9471, desmoplastic nodular medulloblastoma; 9472, medullomyoblastoma; 9474, large cell medulloblastomas. 


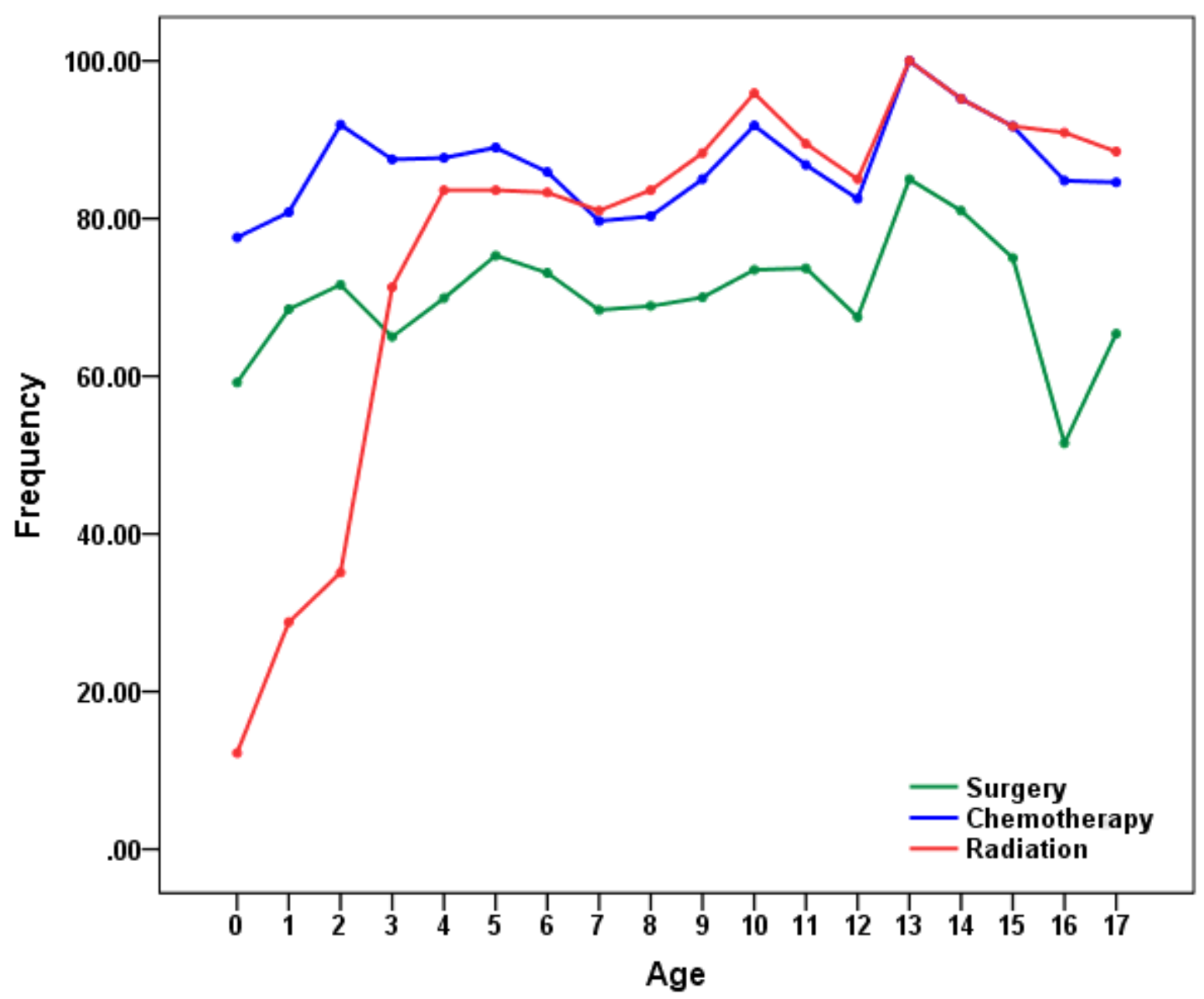

Figure 2

Line chart shows the percent of medulloblastoma patients received surgery, chemotherapy and radiation in every age strata. 